\title{
THE EFFECT OF TRIACONTANOL ON SHOOT MULTIPLICATION AND PRODUCTION OF ANTIOXIDANT COMPOUNDS IN SHOOT CULTURES OF SALVIA OFFICINALIS L.
}

\author{
IZABELA GRZEGORCZYK ${ }^{1}$, IRENEUSZ BILICHOWSKI ${ }^{2}$, \\ ElŻBIETA MIKICIUK-OLASIK ${ }^{2}$, HALINA WYSOKIŃSKA ${ }^{1}$ \\ ${ }^{1}$ Department of Biology and Pharmaceutical Botany \\ 2 Department of Pharmaceutical Chemistry and Drugs Analysis \\ Medical University of Łódź \\ Muszyńskiego 1, 90-151 Łódź, Poland \\ 1 e-mail: botanika@pharm.am.lodz.pl
}

(Received: September 9, 2005. Accepted: December 22, 2005)

\begin{abstract}
This report describes the effect of triacontanol on shoot multiplication and production of antioxidant compounds (carnosic acid, carnosol and rosmarinic acid) in S. officinalis cultures grown on MS basal medium (agar solidified medium supplemented with $0.1 \mathrm{mg} \mathrm{l}^{-1} \mathrm{IAA}, 0.45 \mathrm{mg} \mathrm{l}^{-1} \mathrm{BAP}$ ). It was found that shoot proliferation significantly increased when triacontanol at concentrations of 5,10 or $20 \mu \mathrm{g} \mathrm{l}^{-1}$ was added to the medium. HPLC analysis of acetone and methanolic extracts of sage shoots showed that the production of diterpenoids, carnosic acid/carnosol ratio, as well as, contents of rosmarinic acid were also affected by the treatment with triacontanol. The highest stimulation effect of triacontanol was observed on the production of carnosol, where the treatment with $20 \mu \mathrm{g} \mathrm{l}^{-1}$ increased the content of this diterpenoid 4.5 -fold compared to that in the control (sage shoots growing on MS basal medium, only).
\end{abstract}

KEY WORDS: carnosic acid, carnosol, rosmarinic acid, Salvia officinalis, shoot cultures, triacontanol.

\section{INTRODUCTION}

Salvia officinalis L. (Lamiaceae) is one of the best known species of the genus Salvia and is widely used in official and traditional medicine. Leaf extracts of this plant exhibited a wide range of biological activities i.e. antibacterial (Farag et al. 1989), antiviral (Tada et al. 1994) or anti-inflammatory (Baricevic et al. 2001). The plant is also used commercially in foodstuff for its antioxidant properties. It has been reported that natural antioxidants reduce damage of cellular components, such as lipids, proteins and DNA, and help to prevent mutagenesis, carcinogenesis and aging due to their radical scavenging activities (Haraguchi et al. 1995). The sage (besides rosemary) is considered in the top of the plant species with the strongest antioxidant activities among herbs. This is attributed to the presence of abietane diterpenoids, among them carnosic acid (CA) and carnosol (Car) in aerial parts of $S$. officinalis plants and rosmarinic acid (RA) (Cuvelier et al. 1994). The last compound occurs both in leaves and roots of the plants. It has been shown that carnosic acid and carnosol inhibit cytochrome P 450 activation of carcinogenesis in human cells in vitro (Offord et al. 1995) and enhance the activities of conjugating enzymes involved in carcinogen detoxification pathways in vivo (Singletary 1996).

We have previously reported on the micropropagation procedure and antioxidant compound contents (CA, Car and RA) in in vitro cultured shoots and micropropagated plantlets of S. officinalis. It was also shown that the amounts of the compounds produced under in vitro conditions were lower than those in naturally growing plants (Grzegorczyk et al. 2005). Now, we report the effect of triacontanol (TRIA) on S. officinalis shoot multiplication and production of compounds with antioxidant activity.

Triacontanol, a long 30-carbon saturated primary alcohol, was discovered in 1933 as a natural component of epicuticulary waxes of Medicago sativa (Chibnall et al. 1933). The plant growth stimulating properties of TRIA (such as, increase in dry weight, leaf area and level of reducing sugars, amino acids, soluble proteins and total nitrogen) have been demonstrated by many researchers in various plant species (Ries 1985). Some authors have observed the role of TRIA in micropropagation of ornamental and other plants (Kissimon et al. 1999; Reddy et al. 2002). However, 
very few information is available on the effect of this natural growth regulator on biosynthesis of secondary metabolites.

\section{MATERIALS AND METHODS}

The shoot tips $(0.5 \mathrm{~cm})$ from in vitro shoots of $S$. officinalis, cultured on MS (Murashige and Skoog 1962) 0.7\% agar (provided by Sigma-Aldrich) medium supplemented with $0.1 \mathrm{mg} \mathrm{l}^{-1}$ IAA and $0.45 \mathrm{mg} \mathrm{l}^{-1} \mathrm{BAP}$, were used as explants for shoot multiplication (Grzegorczyk and Wysokińska 2004). In order to study the effect of triacontanol, a single explant was placed in each $25 \times 190 \mathrm{~mm}$ culture tube containing $25 \mathrm{ml}$ of above-mentioned type medium supplemented with TRIA at concentrations of $0,5,10$ or 20 $\mu \mathrm{g} \mathrm{1^{-1 }}$. TRIA was dissolved in chloroform and gradually diluted with distilled water according to Tantos et al. (1999). MS medium with auxin ( $0.1 \mathrm{mg} \mathrm{l}^{-1}$ IAA) and cytokinin (0.45 $\left.\mathrm{mg} \mathrm{l}^{-1} \mathrm{BAP}\right)$, but without TRIA, served as the control. The $\mathrm{pH}$ of all media were adjusted to 5.6-5.9 prior to autoclaving. The media were sterilized by autoclaving at $121^{\circ} \mathrm{C}$ for $17 \mathrm{~min}$.

All cultures were maintained at $26 \pm 2^{\circ} \mathrm{C}$ under a photoperiod of $16 \mathrm{~h}$ with cool-white fluorescent lamps at a PPED of $40 \mu \mathrm{M} \mathrm{m}^{-2} \mathrm{~s}^{-1}$.

For evaluation of the effect of triacontanol the number and length of shoots, as well as their fresh and dry weight were measured after 5 weeks of culture.

\section{Extraction and determination of antioxidant compounds}

Crude extracts for quantitative analysis were obtained by adding $250 \mathrm{mg}$ of air-dried and powered shoots to acetone (sample for diterpenoid analysis) or to methanol (for RA analysis). Acetone and methanolic extracts were analyzed by HPLC. The analysis was performed on a Waters (Milford, USA) Symetry ${ }^{\circledR}$ C18 column $(4.6 \times 150 \mathrm{~mm}, 3.5 \mu \mathrm{m})$ with $2 \mathrm{~cm}$ guard column. The Waters LC system consisted of a Water 600 pump and a Water 996 Photodiode detector, a Waters 717 plus Autosampler was used (injection volume was $5 \mu \mathrm{l})$. The details of extraction procedure and HPLC analysis were described in our previous work (Grzegorczyk et al. 2005). CA, Car and RA were identified by comparison of their retention times and UV spectra with authentic samples under identical conditions. The quantification of these compounds was achieved using calibration curves prepared with standard compounds. RA was purchased from Carl Roth $\mathrm{GmbH}$, while carnosol and carnosic acid were provided by Cayman Chemical Company and Sigma-Aldrich, respectively. The calibration curves obtained for all three compounds gave good correlation values ( $r=0.9841-0.9999)$. The recovery of the known quantities of CA, Car, RA added to biomass sample was 98.3, 96.84 and $98.63 \%$, respectively. HPLC separation of acetone and methanolic extracts of $S$. officinalis shoots cultured in vitro is shown in Figures 1 and 2.

\section{Statistical analysis}

Significance of treatment effects was determined using U Mann-Whitney test $(\mathrm{p}=0.05)$. All experiments were conducted with three replicates for each treatment.

\section{RESULTS AND DISCUSSION}

The shoot tips of Salvia officinalis were incubated on agar-solidified MS medium supplemented with IAA and BAP. The combination of the growth regulators was selected on the basis of our earlier report (Grzegorczyk and Wysokińska 2004). Under these conditions shoot proliferation occurred as a result of the release of axillary buds from apical dominance. In order to examine the effect of TRIA, the growth regulator at concentrations of 5,10 , or $20 \mu \mathrm{g} \mathrm{l}^{-1}$ was added to the shoot multiplication medium. The best response with respect to shoot proliferation was obtained on medium containing $10 \mu \mathrm{g} \mathrm{l}^{-1}$ of TRIA. Thus almost 6 new shoots were formed from single explant within 5 weeks (Table 1). At lower $\left(5 \mu \mathrm{g} \mathrm{l}^{-1}\right)$ or higher $\left(20 \mu \mathrm{g}^{-1}\right)$ concentration the effect of TRIA was less effective, but still induced more shoots than it was found with the untreated control (shoots grown on MS medium without TRIA). The effectiveness of TRIA in shoot proliferation has been earlier reported for several other herbaceous plants such as Melissa officinalis (Tantos et al. 1999), Bupleurum fruticosum (Fratanele et al. 2002) and woody (e.g. Malus domestica) plants (Tantos et al. 2001). The experiments on Melissa officinalis performed by Tantos et al. (1999) have shown that TRIA had a positive effect on both multiplication and

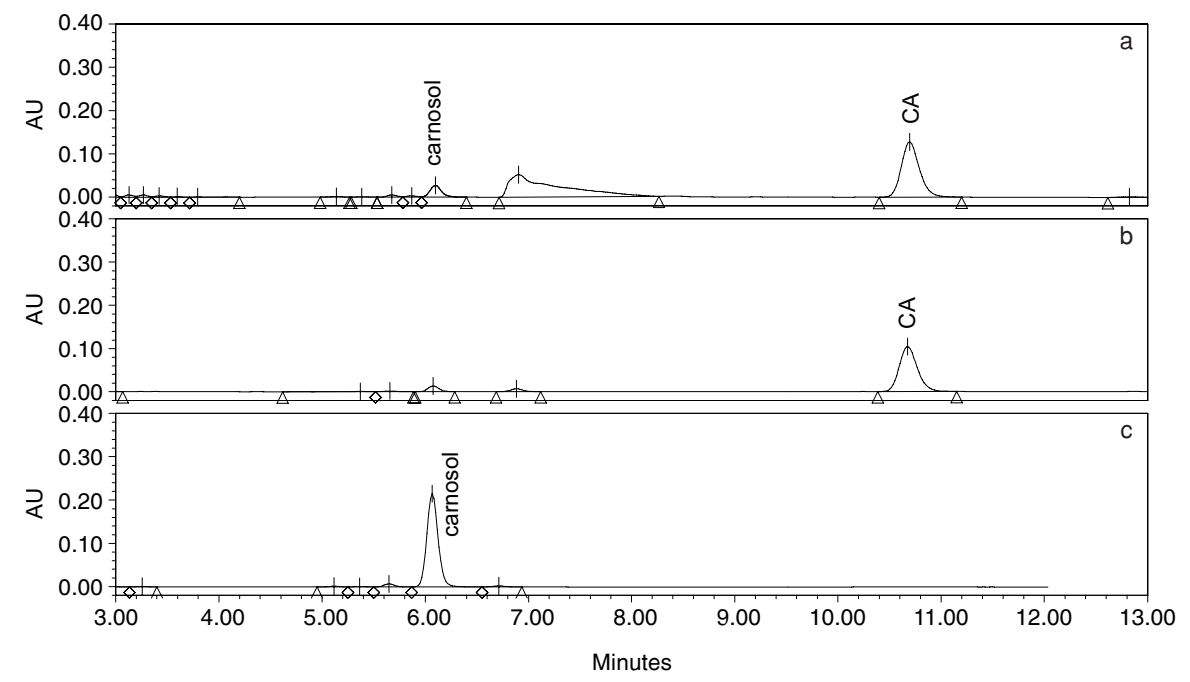

Fig. 1. HPLC chromatogram of acetone extract of sage shoots (a), standard of carnosic acid (CA) (b), standard of carnosol (c). Waters Symetry ${ }^{\circledR}$ column $(4.6 \times 150 \mathrm{~mm}, 3.5$ $\mu \mathrm{m})$; mobile phase: acetonitrile/0.1\% o-phosphoric acid 65:35 (v/v), detection at $230 \mathrm{~nm}$. 


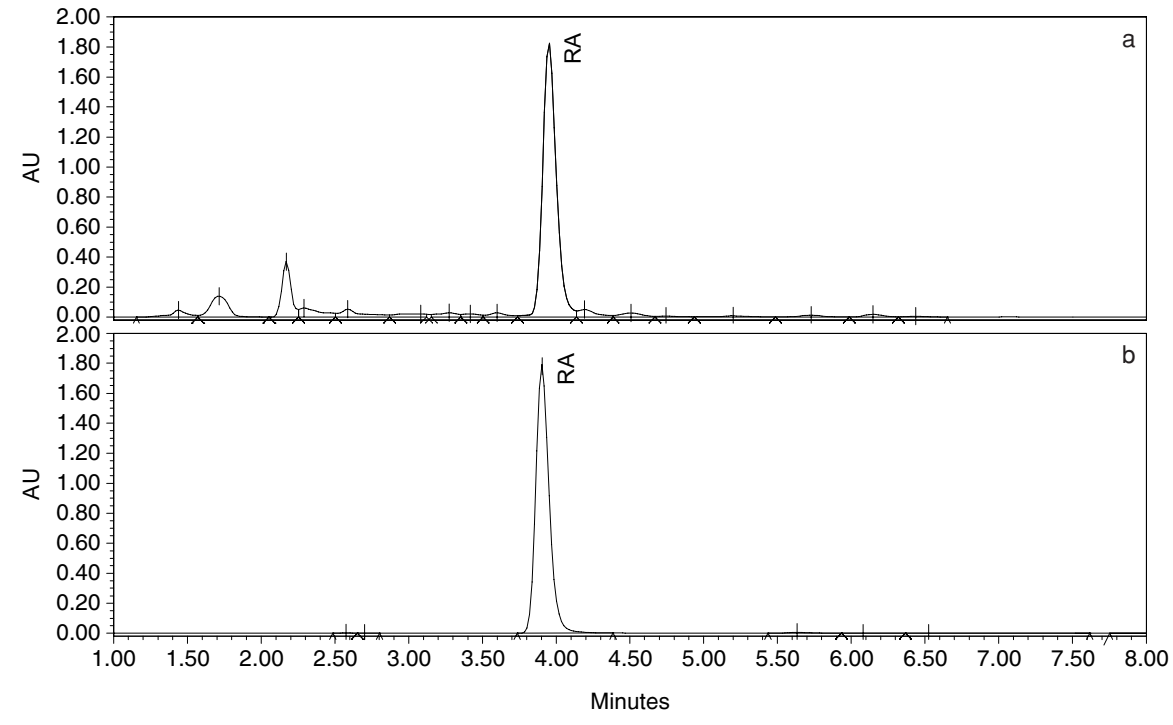

Fig. 2. HPLC chromatogram of methanol extract of sage shoots (a), standard of rosmarinic acid (RA) (b). Waters Symetry ${ }^{\circledR}$ column $(4.6 \times 150 \mathrm{~mm}, 3.5 \mu \mathrm{m})$; mobile phase: acetonitrile $/ 0.1 \%$ o-phosphoric acid $30: 70(\mathrm{v} / \mathrm{v})$, detection at $330 \mathrm{~nm}$.

TABLE 1 . The effect of TRIA on multiplication and growth of $S$. officinalis. Shoots grown on solid MS medium supplemented with IAA $\left(0.1\right.$ mg $\left.1^{-1}\right)$ and $\operatorname{BAP}\left(0.45 \mathrm{mg} \mathrm{l}^{-1}\right)$ for 5 weeks.

\begin{tabular}{cccccc}
\hline $\begin{array}{c}\text { TRIA } \\
\left(\mu \mathrm{g} \mathrm{l}^{-1}\right)\end{array}$ & $\begin{array}{c}\text { Number } \\
\text { of explants }\end{array}$ & $\begin{array}{c}\text { Average shoot length } \\
(\mathrm{cm})\end{array}$ & $\begin{array}{c}\text { Average shoot } \\
\text { number/explant }\end{array}$ & Fresh weight & Dry weight \\
\hline 0 & 40 & $2.26 \pm 0.14 \mathrm{a}$ & $3.32 \pm 0.19 \mathrm{a}$ & $0.49 \pm 0.03 \mathrm{a}$ & $0.04 \pm 0.003 \mathrm{a}$ \\
5 & 35 & $2.16 \pm 0.11 \mathrm{a}$ & $3.97 \pm 0.30 \mathrm{a}$ & $0.49 \pm 0.03 \mathrm{a}$ & $0.04 \pm 0.003 \mathrm{a}$ \\
10 & 35 & $2.08 \pm 0.10 \mathrm{a}$ & $5.60 \pm 0.29 \mathrm{~b}$ & $0.61 \pm 0.03 \mathrm{~b}$ & $0.05 \pm 0.003 \mathrm{~b}$ \\
20 & 36 & $1.69 \pm 0.09 \mathrm{~b}$ & $5.00 \pm 0.33 \mathrm{~b}$ & $0.51 \pm 0.02 \mathrm{a}$ & $0.04 \pm 0.002 \mathrm{ab}$ \\
\hline
\end{tabular}

The values are the means \pm SE. The means in the column followed by the same letter do not differ statistically at $p=0.05$.

rooting phases. Also, in the case of Decalepis hamiltonii (Reddy et al. 2002) the number of roots and their length significantly increased at TRIA concentration of $10 \mathrm{\mu g} \mathrm{l}^{-1}$. However, we observed that root formation was not improved by TRIA at concentration which is responsible for $S$. officinalis shoot multiplication (data not shown). Generally, TRIA also enhanced elongation of multiple shoots and micropropagated plantlets, although such effect has not been found when the woody plants (Malus domestica and $\mathrm{Ce}$ rasus fruticosa) were treated with this growth regulator (Tantos et al. 2001). Our results showed that TRIA induced a slightly but not statistically significant $(\mathrm{p}=0.05)$ decrease in length of micropropagated shoots of S. officinalis with exception of length of shoots grown at concentration of 20 $\mu \mathrm{g} \mathrm{l}^{-1}$ TRIA, which showed a statistically significant decrease (Table 1). At the same concentration of TRIA $\left(20 \mu \mathrm{g} \mathrm{l}^{-1}\right)$ the inhibitory effect on Melissa officinalis shoot length was also observed (Tantos et al. 1999). The growth measured as fresh and dry weight of $S$. officinalis shoots, was slightly increased (about 20-25\% compared to the biomass of control shoots) at concentration of $10 \mu \mathrm{g} \mathrm{l^{-1 }}$ TRIA. Other tested concentrations $\left(5\right.$ or $20 \mu \mathrm{g} \mathrm{l}^{-1}$ ) gave the same results as TRIA-free medium (Table 1). These data are in agreement with results obtained with sour cherry, where TRIA used at concentrations of 2-20 $\mu \mathrm{g} \mathrm{l}^{-1}$ affected a slight increase in fresh weight of shoots, although this increment was not statistically significant (Tantos et al. 2001). Hangarter and Ries (1978) suggested that the increased growth caused by TRIA is not simply caused by water uptake and cell enlargement but rather by an increase in cell number.
The effect of TRIA on the production of antioxidant compounds

The phenolic compounds with strong antioxidant and radical scavenging properties were extracted with acetone (carnosic acid and carnosol) and methanol (rosmarinic acid) from S. officinalis shoot cultures grown on MS agar medium supplemented with IAA and BAP. The compounds were identified by UV spectra and retention times and their contents were determined by HPLC system. Thus, total diterpenoid yield (calculated as the sum of carnosic acid and carnosol) of $5.25 \mathrm{mg} \mathrm{g}^{-1}$ dry weight was obtained, of which $4.37 \mathrm{mg} \mathrm{g}^{-1}$ dry wt was CA and $0.82 \mathrm{mg} \mathrm{g}^{-1}$ dry wt was Car. RA (12.25 mg g-1 dry wt) was also detected in sage shoots grown on MS basal medium within 5 weeks.

The biosynthesis of secondary metabolites in in vitro cultures is often affected by growth regulators. In order to get information on the influence of TRIA on the production of antioxidant compounds, content of carnosic acid, carnosol and rosmarinic acid in sage shoots grown in the presence of this growth regulator at the concentrations of 5,10 or 20 $\mu \mathrm{g} \mathrm{l}^{-1}$ was investigated. It was found that the maximum level of identified diterpenoids, $10.2 \mathrm{mg} \mathrm{g}^{-1}$ dry wt, was achieved in shoots grown in the presence of $5 \mu \mathrm{g} \mathrm{l^{-1 }}$ TRIA. The value was twice higher than in untreated shoots (Table 2) and comparable with the diterpenoid content in shoots of naturally growing plants of $S$. officinalis (Grzegorczyk et al. 2005). The use of higher TRIA concentrations (10 or $20 \mu \mathrm{g}^{-1}$ ) did not induce further increase in the diterpenoid yield of sage shoots. It is worth mentioning that TRIA treatment increased mainly carnosol content in sage shoots, 
TABLE 2. The effect of TRIA on content of carnosic acid, carnosol and rosmarinic acid in shoot culture of S. officinalis. Shoots grown on solid MS medium supplemented with IAA $\left(0.1 \mathrm{mg} \mathrm{l}^{-1}\right)$ and BAP $\left(0.45 \mathrm{mg} \mathrm{l}^{-1}\right)$ for 5 weeks.

\begin{tabular}{|c|c|c|c|c|}
\hline \multirow{2}{*}{$\begin{array}{l}\text { TRIA } \\
\left(\mu \mathrm{g}^{-1}\right)\end{array}$} & \multicolumn{4}{|c|}{ Compound contents (mg g ${ }^{-1}$ dry weight) } \\
\hline & $\mathrm{CA}$ & Car & $\mathrm{CA}+\mathrm{Car}$ & RA \\
\hline 0 & $4.37 \pm 0.22 \mathrm{a}$ & $0.88 \pm 0.02 \mathrm{a}$ & $5.25 \pm 0.21 \mathrm{a}$ & $12.25 \pm 0.11 \mathrm{a}$ \\
\hline 5 & $6.30 \pm 0.15 b$ & $3.94 \pm 0.09 \mathrm{bc}$ & $10.24 \pm 0.21 \mathrm{~b}$ & $18.50 \pm 0.48 b$ \\
\hline 10 & $5.01 \pm 0.04 \mathrm{c}$ & $3.84 \pm 0.04 \mathrm{~b}$ & $8.85 \pm 0.17 \mathrm{c}$ & $16.35 \pm 0.03 \mathrm{c}$ \\
\hline 20 & $4.59 \pm 0.08 \mathrm{a}$ & $4.13 \pm 0.09 \mathrm{c}$ & $8.72 \pm 0.06 \mathrm{c}$ & $19.98 \pm 0.04 \mathrm{~d}$ \\
\hline
\end{tabular}

The values are the means \pm SE. The means in the column followed by the same letter do not differ statistically at $\mathrm{p}=0.05$ according to $U$ Mann-Whitney test.

with little influence on carnosic acid (the dominant product of untreated shoots). For example the relative ratio of CA to Car in control was approximately $5: 1$, while it was changed to $1.6: 1$ and $1: 1$ in shoots treated with 5 and $20 \mu \mathrm{g}^{-1}$ TRIA, respectively. It indicates that TRIA promoted conversion of carnosic acid to subsequent metabolite i.e. carnosol (higher oxidized diterpenoid with $\delta$-lactone structure). Another interesting result of our work is the increase in RA content in sage shoots treated with TRIA. The shoots which were grown on medium supplemented with $20 \mu \mathrm{g} \mathrm{l}^{-1}$ TRIA showed the highest content of the compound (about $20 \mathrm{mg} \mathrm{g}^{-1}$ dry wt) (Table 2). This value is $63 \%$ over that of the control culture and 41-fold over that of the commercial sage sample ( $482 \mu \mathrm{g} \mathrm{g}^{-1}$ dry wt) reported earlier by SantosGomes et al. (2002). However, the level of RA in TRIA treated sage shoots was much lower than that achieved by Hippolyte et al. (1992) in suspension culture of the same sage species.

The results presented here show that TRIA is an effective growth regulator for $S$. officinalis shoot multiplication. The compound could also be used at a very low concentration to improve antioxidant compounds yield, mainly diterpenoids in shoots of sage species. In this respect, the highest value of carnosic acid and carnosol (about $11 \mathrm{mg} \mathrm{g}^{-1}$ dry wt) obtained in shoots treated with $5 \mu \mathrm{g} \mathrm{1^{-1 }}$ TRIA can be considered a valuable result because it represents a $100 \%$ increase in relation to untreated sage shoots. The ability of TRIA to enhance diterpenoid production might be explained by the fact that biosynthesis of the compounds has probably been localized in the chloroplasts (Munne-Bosch and Alegre 2001), and TRIA is known to increase chlorophyll content in many plants and tissue cultures (Ries 1985).

There are only two instances evaluating the effect of TRIA on biosynthesis of secondary metabolites in in vitro cultures. Fraternale et al. (2003) have observed an increase in the essential oil yield in micropropagated plantlets of Thymus mastichina, when triacontanol was added to hormone-free medium. The addition of TRIA to medium containing BAP, IBA or BAP + IBA did not induce a significant change in the essential oil yield. TRIA enhanced also the production of secondary metabolites in Artemisia annua cultures (Yaseen and Tajuddin 1998). The mechanism for those responses is unknown. Reis and Houtz (1983) suggest that TRIA, like other plant hormones, may activate enzymes or alter a membrane, which triggers a cascading effect resulting in increased metabolism and the accumulation of various critical intermediate metabolic compounds.

\section{ACKNOWLEDGEMENTS}

This work was supported by grant 092/P05/2003.

\section{LITERATURE CITED}

BARICEVIC D., SOSA S., DELLA LOGGIA R., TUBARO A., SIMONOVSKA B., KRASNA A., ZUPANCIC A. 2001. Topical anti-inflammatory activity of Salvia officinalis L. leaves: the relevance of ursolic acid. J. Ethnopharmacol. 75: 125-132.

MUNNE-BOSCH S., ALEGRE L. 2001. Subcellular compartmentation of the diterpene carnosic acid and its derivatives in the leaves of rosemary. Plant Physiol. 125: 1094-1102.

CHIBNALL A.C., WILIAMS E.F., LATNER A.K., PIPER S.H. 1933. The isolation of n-triacontanol from Lucerne wax. Biochem. J. 27: 1885-1888.

CUVELIER M. E., BERSET C., RICHARD H. 1994. Antioxidant constituents in sage (S. officinalis). J. Agric. Food Chem. 42: 665-669.

FARAG R.S., DAW Z.Y., HEWEDI F.M., EL-BAROTY G.S.A. 1989. Antimicrobial activity of some Egyptian spice oils. J. Food Protect. 52: 665-667.

FRATERNALE D., GIAMPERI L., RICCI D., ROCCHI M.B.L. 2002. Micropropagation of Bupleurum fruticosum: The effect of triacontanol. Plant Cell Tiss. Org. Cult. 69: 135-140.

FRATERNALE D., GIAMPERI L., RICCI D., ROCCHI M.B.L., GUIDI L., EPIFANO F. 2003. The effect of triacontanol on micropropagation and on secretory system of Thymus mastichina. Plant Cell Tiss. Org. Cult. 74: 87-97.

GRZEGORCZYK I., WYSOKIŃSKA H. 2004. Mikrorozmnażanie Salvia officinalis L. z wierzchołków pędów. Biotechnologia. 65: 212-218. (in Polish with English summary)

GRZEGORCZYK I., BILICHOWSKI I., MIKICIUK-OLASIK E., WYSOKIŃSKA H. 2005. In vitro cultures of Salvia officinalis L. as a source of antioxidant compounds. Acta Soc. Bot. Pol. 74: 17-21.

HANGARTER R., RIES S. 1978. Effect of triacontanol on plant cell cultures in vitro. Plant Physiol. 61: 855-857.

HARAGUCHI H., SAITO T., OKAMURA N., YAGI A. 1995. Inhibition of lipid peroxidation and superoxide generation by diterpenoids from Rosmarinus officinalis. Planta Med. 61: 333-336.

HIPPOLYTE I., MARIN B., BACCOU J.C., JONARD R. 1992. Growth and rosmarinic acid production in cell suspension cultures of Salvia officinalis L. Plant Cell Rep. 11: 109-112.

KISSIMON J., TANTOS A., MESZAROS A., JAMBOR-BENCZUR E., HORVATH G. 1999. Stress alternation in growth parameters, pigment content and photosynthetic function of in vitro cultured plants. Z. Naturforsch. 54c: 834-839.

MURASHIGE T., SKOOG F. 1962. A revised medium for rapid growth and bioassays with tobacco tissue cultures. Physiol. Plant. 15: 473-497. 
OFFORD E.A., MACE K., RUFFIEUX C., MALONE A., PFEIFER A.M. 1995. Rosemary components inhibit benzo[a]pyrene-induced genotoxicity in human bronchial cells. Carcinogenesis 16: 2057-2062.

REDDY B.O., GIRIDHAR P., RAVISHANKAR G.A. 2002. The effect of triacontanol on micropropagation of Capsicum frutescens and Decalepis hamiltonii W\&A. Plant Cell Tiss. Org. Cult. 71: 253-258

RIES S.K. 1985. Regulation of plant growth with triacontanol. CRC Crit. Rev. Plant Sci. 2: 239-285.

RIES S., HOUTZ R. 1983. Triacontanol as a plant growth regulator. Hort. Sci. 18: 654-662.

SANTOS-GOMES P.C., SEABRA R.M., ANDRADE P.B., FERNANDES-FERREIRA M. 2002. Phenolic antioxidant compounds produced by in vitro shoots of sage (Salvia officinalis L.). Plant Sci. 62: 981-987.
SINGLETARY K.W. 1996. Rosemary extract and carnosol stimulate rat liver glutathione-S-transferase and quinone reductase activities. Cancer Lett. 100: 139-144.

TADA M., OKUNO K., CHIBA K., OHNISHI E., YOSHII T. 1994. Antiviral diterpenes from Salvia officinalis. Phytochemistry 35: 539-541.

TANTOS A., MESZAROS A., KISSIMON J., HORVATH G., FARKAS T. 1999. The effect of triacontanol on micropropagation of balm, Melissa officinalis L. Plant Cell Rep. 19: 88-91.

TANTOS A., MESZAROS A., FARKAS T., SZALAI J., HORVATH G. 2001. Triacontanol-supported micropropagation of woody plants. Plant Cell Rep. 20: 16-21.

YASEEN M., TAJUDDIN K. 1998. Effect of plant growth regulators on yield, oil composition and artemisina of Artemisa annиа under temperature conditions. J. Med. Aromat. Plant Sci. 20: $1038-1041$. 